\title{
FOR UNDERSTANDING OF CHALLENGES OF GEORGIAN LABOUR MARKET
}

\section{MARIAMI KENCHOSHVILI}

PhD Student,

Samtskhe-Javakheti State University, Georgia

Kenchoshvilimari1@gmail.com https://doi.org/10.35945/gb.2018.06.036

\section{KEY WORDS: LABOUR MARIKET, UNEMPLOYMENT, THE RIGHTS OF EMPLOYED, MINIMAL SALARY}

\section{INTRODUCTION}

Unemployment is one of the main challenges of every country, overcoming of which is much depended on active and coordinated work of state and business sectors. Any state regardless the rate of the unemployment shall ensure protection of the interests of employers and employees with respective legislative basis, as a rule it is hard to find a golden medium when the rights of employers and employees will be protected equally. Georgian labour market is far from a golden medium, during 2008-2017 416 people died on their job and 716 were damaged heavily. Since 2011 this statistics tend to be increasing (Human Rights Education and Monitoring Center, 2017:10). The paper demonstrates the view of the author, about key challenges of Georgian labor market and overcoming ways.

\section{KEY CHALLENGES OF GEORGIAN LABOUR MARKET}

Unemployment is the main challenge for the population in Georgia. It is demonstrated in the International Republican Institute (IRI) survey of April 10-22, 2018. According to the survey, $27 \%$ of the interviews considers that the main problem of their families is unemployment. $26 \%$ of the interviewed thinks that unemployment is the key problem faced by the city or village, while $40 \%$ of the interviewed considers that unemployment of the main problem for Georgia (IRI survey, 2018).

According to the official annual publication about employment and unemployment 2017 of the National Statistics Service of Georgia, the official level of the unemployment in Georgia is $13.9 \%$. The share of self-employed among employed is $51.7 \%$. As for the regional prospective compared to the previous year the situation was improved in Adjara Autonomic Republic, Samegrelo-ZemoSvaneti and Kakheti regions. From the age prospective the situation is difficult for 20-24 and 25-29 age groups, as unemployment rate in the mentioned age groups comprises 29.6\% and $20.8 \%$ (The National Statistics Service of Georgia,2017).

The official annual publication about employment and unemployment of the National Statistics Service of Georgia is developed in accordance to the methodology of the International Labour Organization and each person who lives in the village has its own land plot or has any kind of domestic animal and applies extra production for selling, is considered as an employed (The National Statistics Service of Georgia, general definitions). From the regional prospective, there is unnaturally low rate of unemployment in Samtskhe-Javakheti- 5.9\%, It is caused by the methodological lacks and actually unemployment rate is several times higher in Samtskhe-Javakheti than it is given in the publication of National Service of Statistics of Georgia.

Noteworthy, that Georgian Government developed the decree \#199 of August 2, 2013 "On Approval of the State Strategy about formation of the labour market in Georgia and implementation of 2015-2018 Action Plan" (Decreeof Georgian Government \#199 of August 2, 2013) and the decree \# 167 of April 04, 2016 about "Labour market active policy strategy and approval of implementation for 2016-2018" for development of the labour market in Georgia (Decreeof Georgian Government \# 167 of April 04, 2016). Though above-mentioned normative acts are kind of conceptual and legal basis for achievement the goals which requires coordinated work on all the levels and in every field by the government and the impact of the results will be in the field of labor market development in nearest future

The challenges on the labor market does not include only limited number of the workplaces, lack of qualified human resource, need for favorable business environment for investors or implementation of the reforms in the education sector. Due to such a high level of the unemployment the social situation is very poor in the country. Employed as well as unemployed have to agree with the cabal labor conditions without hesitation, which they have sometimes to repay by their 
lives, therefore it is necessary to improve legal basis for ensuring rights of employed from the side of the state and regular monitoring, as people almost at every stage of labor relationship face with discriminative elements starting from hiring till termination of labor relationship. In Georgia before hiring a person, in the description of various vacancies we often meet the phrases, like, women, men, pleasant looking, young, does not consider without a photo, as well as the questions during the interviews referring not only to professional issues, but to personal aspects as well, like marital status, plan of having children, etc.

We have analyzed the vacancies selected randomly published during 09.11.2018-16.11.2018 on the public service bureau web-site hr.gov.ge and one of the most visited web-sites hr.ge during the research 142 vacancies from hr.gov.ge and 145 from hr.ge were analyzed. It appeared that the situation is quite improved based on the research conducted within the framework of the project "Support to the Gender equality on the jobs" conducted by the non-governmental organization "Article 42 of the Constitution" (The Article 42 of the Constitution, 2016) as no vacancy published by the public service bureau did not included discriminative elements. While 11 out of randomly selected 145 vacancies from hr.ge included different kind elements of direct discrimination.

The situation is difficult in terms of labor agreements. According to the EWMI research aiming evaluation of the labor inspection mechanisms and the study of labor rights of employed in Georgia sometimes employed has no access to agreements and the possibility to introduce with them and they are obliged to sign it without reading, otherwise, their action is considered as suspicious and non-reliable what can become the reason for failure of signing an agreement. The result can be assessed as dangerous and unhuman confronting to all basic human rights (Human Rights Education and Monitoring Center, 2016:76-78). Regardless above mentioned research included limited list of the activities we can say that research objects did not know about employees' motivation .

One of the actual problems in the labor relationship is working conditions and duration of the work, according to the labor Code, the number of working hours during the week shall not exceed 40 hours, while it shall not exceed 48 hours in the fields and sectors with special regime. The time exceeding them is considered as overtime which shall be remunerated by the increased hourly salary rate (Labor Code). One fundamental problem is important, that gives an employer the opportunity to continue exploiting the employees during overtime work with support of the legislation, as law does not regulate the minimum salary which is relevant to merit, but it meets the basic needs of the people. According to the world experience there are following ways of calculation of overtime labor on an hourly basis, like 1,$1 ; 1,2 ; 1,5$ etc, Georgian legislation does not define the hourly rate of overtime work which is one of the important challenges in labor relationship.

A public defender always focuses on its annual report about necessity of regulating minimal salary for 2015-2016. Currently the law defines 40 GEL as a minimal salary (The Ordinance of the President of Georgia, \# 767, 2006). Exceptions are the people working in the public services and public schools for which minimal quantity of labor remuneration is defined separately, which several times exceeds the minimal rate of labor remuneration on the country level (The Order \# 126/n of the Minister of Education and Science of Georgia, 2015).

The office of public defender together with trade union of Georgia the compliance of minimal salary policy was studies with support of Fredrich Ebert Stiftung considering social-economic development and international responsibilities of Georgia in 2016. The study highlights once again the need for defining of rational quantity minimal salary, according to the study by March 2016 in Georgia 25,001 people has less than 100 GEL, 62, 681 men in the employable age have the salary below living minimum, while 130, 282 people have the salary below living minimum of family (Trade Union of Georgia, with support of Fredrich Ebert Stiftung, Office of Georgian

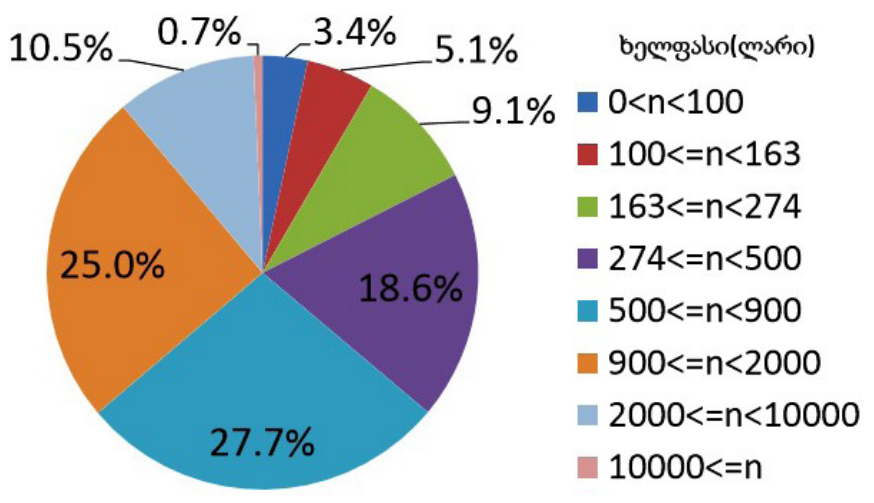

Public Defender, 2016).The intervals of the gross salaries are as follows:

1. Intervals of the gross salaries 2016. 
Source: Trade Union of Georgia, The office of public defender, 2016

Regardless the fact that there are many methods of evaluation of market value of intellectual capital, but unemployment rate is so high in Georgia, that employers do not spend time and energy in this direction Opposition to the minimal salary defining use the Germany example as an argument, where in 2015 declaration of the minimal salary on the legislative level reduced employment places into 60,000 . It is interesting, that they ignore the second part of the medal as even in Germany, which is one of the European countries with the leading economy where 60,000 people got the salary below the minimum, we can imagine what will be the number of the people who works for the salary below minimal salary.

The social situation is very poor in the country. According to the official survey about the financial access of The World Bank the number of borrowers from commercial banks in Georgia per 1000 adults is 724 for 2016 year (The World Bank, 2016).

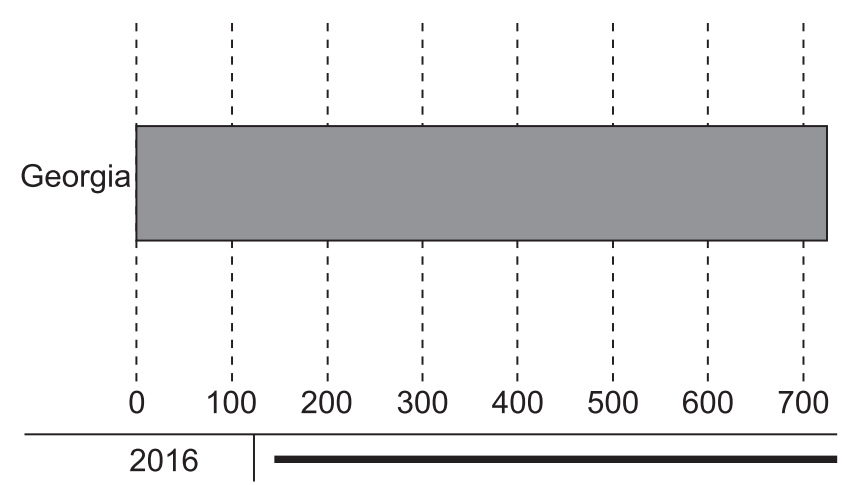

L. Ivumper of porrowers Jrom commercıaı panks per 1000 adults. Source: The World Bank

The limited mandate of a labor inspection is another challenge for Georgian labor market. In 2018 Georgian Government made an important step, the law about safety of labor was developed though the law covers only those people who are engaged in the hazardous, heavy and dangerous work types (Organic Law of Georgia low about safety of labor) while the inspection of the work conditions of the employees for all other kind of jobs takes place pursuant to decree \#603 of Georgian government of December 29, 2017 "State program of labor condition inspection of 2018", according to which the inspection shall be implemented only in case of permission of the employers and the role of the labor inspection is only preventive, it is limited with the consultation and information provision (Decree of Georgian Government \# 603, 2017). In the developed countries labor inspection is the mechanism for protection of labor conditions, as well as implemented of the labor right monitoring which assigned to identify the violations and define preventive measures. They provide recommendations not only post-factum, but also pre-factum and have effective instrument to make implementation of the recommendations obligatory for employers. Unlike Georgian labor inspection, they are able to implement inspection and monitoring activities without preliminary informing of the employer, any time of day and night. It increases the efficiency level of their work. Therefore, improvement of the labor inspection mandate still remains as an important challenge of state labor market.

\section{CONCLUSIONS}

For coping with the problems available on labor market of Georgia, the Georgian Government made important steps, though for increasing efficiency it is important:

- Comprehensive and systematic work on every level of state structures for implementation of the state strategy for formation labor market of Georgia and active policy strategy of labor market and later on for continuation of the policy;

- To ensure review of the minimal salary policy by the respective state agencies and adjustment to the demands of Georgian labor market;

- Respective state services ensure defining the rate of overtime work in terms of hourly renumeration;

- Respective state agencies shall ensure enhancement of the labor inspection mandate in order healthy working environment is the basis for healthy economics. 


\section{REFERENCES:}

1. Decree of Georgian Government №603 of December 27, (2017). "regarding to approval of state program regarding to inspecting of Labor conditions 2018".

2. Decreeof Georgian Government №167 of April 04, (2016). "Labor market active policy strategy and approval of implementation for 2016-2018" for development of the labor market in Georgia.

3. Decreeof Georgian Government №199 of August 2, (2013). “On Approval of the State Strategy about formation of the labor market in Georgia and implementation of 2015-2018 Action Plan"

4. Human Rights Education and Monitoring Center, "Evaluation of labor inspection mechanisms and labor rights of employees in Georgia", (2017). Tbilisi. (https://emc.org.ge/ka/products/kvleva-shromis-inspektirebis-mekanizmis-shefaseba-da-dasakmebulta-shromiti-uflebebis-mdgomareoba-sakartveloshi )

5. Human Rights Education and Monitoring Center ."Evaluation of labour inspection mechanisms and labour rights of employees in Georgia", (2017). Tbilisi, p. 76-78. (https://emc.org.ge/ka/products/kvleva-shromis-inspektirebis-mekanizmis-shefaseba-da-dasakmebulta-shromiti-uflebebis-mdgomareoba-sakartveloshi)

6. INTERNATIONAL REPUBLICAN INSTITUTE. PUBLIC OPINION SYRVEY: RESIDENTS OF GEORGIA APRIL 10-22 (2018). (http:// www.iri.org/sites/default/files/2018-529_georgia_poll_presentation.pdf?fbclid=IwAR1OgbC496zEDCLNYK6JxdKqylnJWCxTwDAmMrMsz64IVTPDVNp6pSsNpJ8)

7. Organic Law of Georgia, labor Code

8. Organic Law of Georgia low about safety of labor

9. Trade Union of Georgia, with support of Fredrich Ebert Stiftung, Office of Georgian Public Defender, Checking of relevant salary policy from the prospective of social and economic development of Georgia and international obligations. (2016). (http://www.ombudsman.ge/uploads/other/3/3992.pdf)

10. TheNational Statistics Service of Georgia, Employment and unemployment in Georgia, (2017).

11. The National Statistics Service of Georgia, general definitions about statistical methodology of labor power

12. "The Article 42 of the Constitution. Gender discrimination in labor relationships, Tbilisi, the survey is produced by the "The Article 42 of the Constitution under the project "Support to Gender equality on the labor places" ttps://article42.ge/ media/1001447/2017/09/11/6c0cb0d69764bea21f32052f5abce8ce.pdf)

13. The Ordinance of the President of Georgia, (2006), №767 of December 26. about "Minimal Salary" About changes in the Ordinance № 351 of the President of Georgia of June 4, 1999

14. The Order № 126/n of the Minister of Education and Science of Georgia, (2015). September 28, on defining the quantity and conditions of minimal remuneration of teachers' labour of Public Schools"

15. The World Bank, survey about financial access. (2016). https://data.worldbank.org/indicator/FB.CBK.BRWR.P3?end=2016\&locations=GE\&start=2016\&view=bar

16. The web site- https://www.hr.ge/

17. The website of public service bureau /https://www.hr.gov.ge/ 


\section{FOR UNDERSTANDING OF CHALLENGES OF GEORGIAN LABOUR MARKET}

MARIAMI KENCHOSHVILI

https://doi.org/10.35945/gb.2018.06.036

PhD Student,

Samtskhe-Javakheti State University, Georgia

Kenchoshvilimari1@gmail.com

\section{KEY WORDS: LABOUR MARKET, UNEMPLOYMENT, THE RIGHTS OF EMPLOYED, MINIMAL SALARY}

\section{SUMMARY}

Nowadays, unemployment is one of the main challenges of every country, but it is not the only problem for labor market in Georgia. For coping with the problems available on labor market of Georgia, the Georgian Government made important steps, though for increasing efficiency it is important:

- Comprehensive and systematic work on every level of state structures for implementation of the state strategy for formation labor market of Georgia and active policy strategy of labor market and later on for continuation of the policy;

- To ensure review of the minimal salary policy by the respective state agencies and adjustment to the demands of Georgian labor market;

- Respective state services ensure defining the rate of overtime work in terms of hourly renumeration;

- Respective state agencies shall ensure enhancement of the labor inspection mandate in order healthy working environment is the basis for healthy economics. 